\title{
Rbipidia Meigen, 1818 (Diptera: Limoniidae): a new species from India and a new record for the Palaearctic region
}

\author{
Rbipidia Meigen, 1818 (Diptera: Limoniidae): новый вид из Индии \\ и новая находка Аля Палеарктической области
}

\author{
D.I. Gavryushin \\ А.И. Гаврюшин
}

\begin{abstract}
Zoological Museum, Moscow Lomonosov State University, Bol'shaya Nikitskaya 6, Moscow 125009 Russia. E-mail: dmitry_gavryushin@yahoo.com

Зоологический музей, Московский государственный университет им. М.В. Ломоносова, Большая Никитская ул., 6, Москва 125009 Россия.
\end{abstract}

KEYWORDS: Diptera, Limoniidae, Rhipidia, India, Canary Islands, taxonomy, description, new species, new record.

КЛЮЧЕВЫЕ СЛОВА: Diptera, Limoniidae, Rhipidia, Индия, Канарские острова, таксономия, описание, новый вид.

ABSTRACT. A new species of Rhipidia Meigen, 1818 is described from India. Description of male, illustrations of male genitalia, wing, and other structures are provided. Rhipidia schwarzi Alexander, 1912 is recorded from the Palaearctic region (Canary Isands) for the first time. Male genitalia are described and illustrated.

РЕЗЮМЕ. Описан новый вид рода Rhipidia Meigen, 1818 из Индии. Даны описание самца, иллюстрации гениталий самца, крыла и других структур. Rhipidia schwarzi Alexander, 1912 впервые отмечена для Палеарктической области (Канарские острова). Даны описание и иллюстрации гениталий самца.

\section{Introduction}

While studying short-palped crane-flies (Limoniidae) collected in North India (the state of Uttarakhand) in September 2011 by N. Vikhrev, a species new to science belonging to the nominative subgenus of the genus Rhipidia Meigen, 1818 (subfam. Limoniinae) was discovered. Rhipidia (s.str.) Meigen, 1818 is a vast group of short-palped crane-flies (Limoniidae) with ca. 200 taxa described worldwide and 23 species known so far from the Oriental region [Oosterbroek, 2012]. The main diagnostic features of the subgenus are as follows: antennae 14-segmented (13-segmented being a rare exception, as in Rhipidia polythrix (Alexander, 1978) from Panama), cell $d m$ closed, relatively big size, spines on rostral projection variable in number, size, and position, but never arising from a common enlarged basal tubercle as in Rhipidia (Eurhipidia) and some Dicranomyia.

\section{Material and methods}

The morphological terms used here mainly follow McAlpine [1981], venation is described mostly after Alexander and Byers [1981]. Details of colouration were checked in dry-mounted specimens only. Male genitalia were boiled in $10 \%$ solution of potassium hydroxide $(\mathrm{KOH})$ for 60 to $90 \mathrm{~s}$, neutralised by a $10 \%$ solution of acetic acid $\left(\mathrm{CH}_{3} \mathrm{COOH}\right)$, washed in water and then stored in glycerine. Wings in glycerine were photographed with a Nikon D70s DSLR camera; microphotographs of genitalia and other structures were prepared using an eTREK DCM900 camera on MBI-1 microscope and processed with CombineZP software. Type material is deposited in the Zoological Museum of the Moscow State University (ZMMU).

\section{Species description}

\section{Rhipidia scopifera sp.n.}

$$
\text { Figs 1-11. }
$$

MATERIAL. Holotype $\sigma^{7}$, India, Uttarakhand, Chamba, $30.363^{\circ} \mathrm{N}, 78.384^{\circ} \mathrm{E}, 1800 \mathrm{~m}, 9-10 . I X .2011$, N. Vikhrev (ZMUM). Holotype is dry-mounted, glued to an insect pin, terminal antennal flagellomeres broken, wings intact, all legs but two (right mid leg and right hind leg) missing.

Paratype $\sigma^{7}$, India, Uttarakhand, Chamba, $30.363^{\circ} \mathrm{N}, 78.384^{\circ} \mathrm{E}$, 1800 m, 9-10.IX.2011, N. Vikhrev, in a spider's web (ZMUM).

DIAGNOSIS. Medium-sized brownish-yellow species with holoptic eyes, a small horn-like process above the antennae, long-bipectinate antennal flagellomeres, weakly developed dark stripes on pleurae, very conspicuous tufts of long hairs on 6th abdominal segment laterally, and wing pattern of numerous brownish-grey 

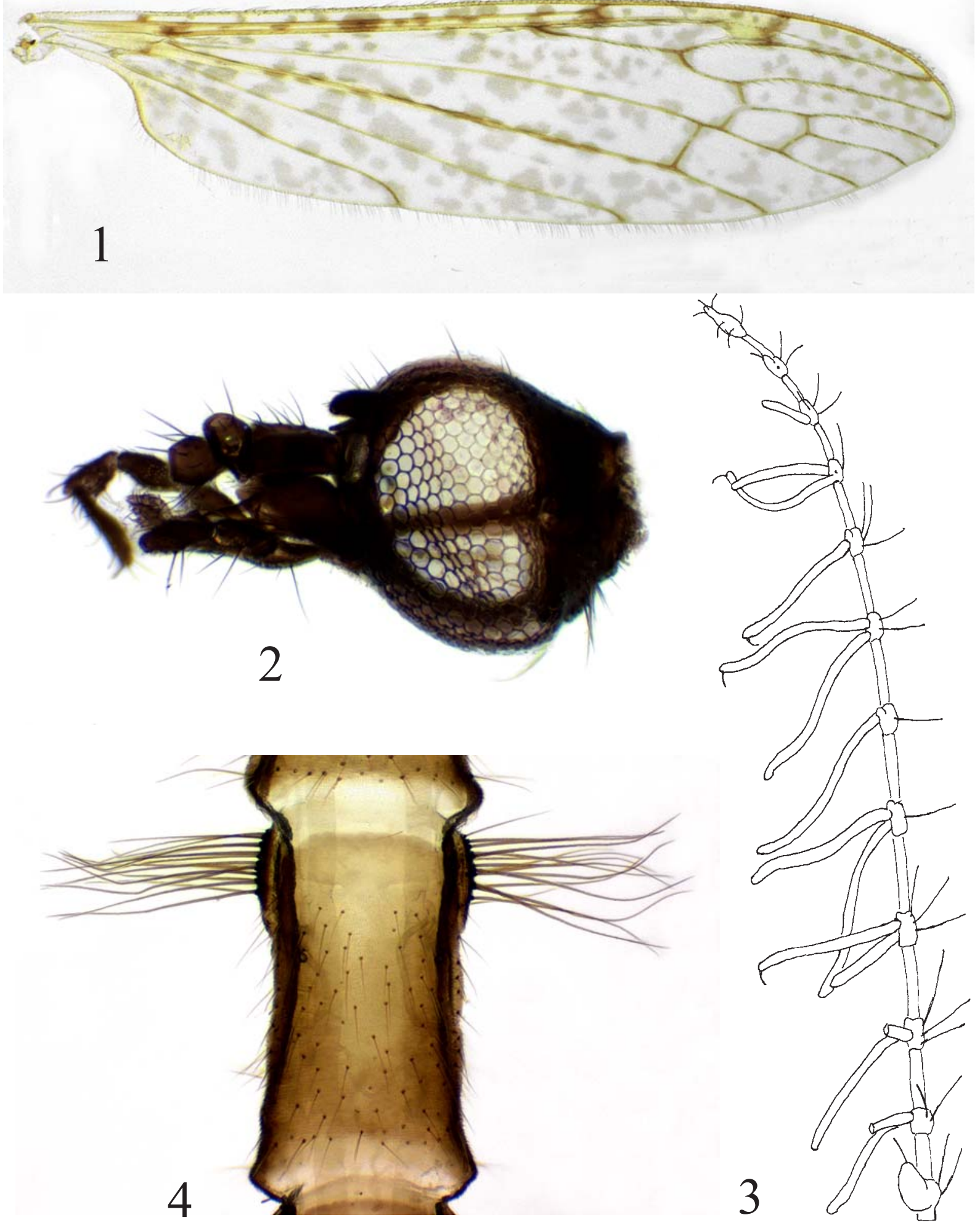

Figs 1-4. Rhipidia scopifera sp.n., paratype $0^{7}: 1-$ wing; 2 - head, left lateral view (antennal flagellomeres removed); 3 flagellum; $4-6$ th abdominal segment, ventral view.

Рис. 1-4. Rhipidia scopifera sp.n., паратип о : 1 - крыло; 2 - голова, вид сбоку слева (флагелломеры антенны удалены); 3 флагеллум; 4 - 6-й сегмент брюшка, вид снизу. 
spots in all cells. Body length and wing length ca. $7 \mathrm{~mm}$.

DESCRIPTION. Male. Head (Fig. 2) grey, posterior vertex and lower surface with several long hairs, rostrum and palpi brown, with long hairs, rostrum rather long, ca. 0.7 length of head. Eyes big, appearing holoptic both on upper and lower surface of head in dry specimens; however, examination of prepared head revealed a capillary strip of frons, its minimum width less than diameter of ommatidia. Frons with a dark-brown horn-like process above the bases of antennae, its length approx. 0.3 length of the scape, and a pair of microscopic spine-like processes just below it. Antennae ca. $2 \mathrm{~mm}$ in length, scape and pedicel yellowish-brown, with long hairs, scape elongate-cylindrical, approx. twice as long as pedicel, pedicel subglobular, antennal flagellomeres (Fig. 3) with yellowish apical necks, first flagellomere with a short neck and a single dark-brown lobe, its length roughly equal to that of the segment. Flagellomeres 2 to 9 ventrally each with two long darkbrown appendages, the longest are those of flagellomeres 6 and 7, almost twice as long as their stems; appendages of flagellomeres 2 and 9 are the shortest of all; all these appendages have short curved bristles on their lower apical surfaces. Flagellomere 10 with a single pectination roughly equal in length to the segment, flagellomere 11 with even shorter single appendage, only slightly longer than width of the segment; ultimate flagellomere not branched, with a produced dark-brown apex bearing several short curved bristles. All branched flagellomeres with 3 outstanding hairs at base dorsally, their length up to 0.8 length of the segment.

Thorax almost uniformly light brownish-yellow, densely yellowish-grey pollinose, including lateral margins of praescutum, scutellum and pleurae, that pollinosity is clearly visible at certain angles of view, the regions where pollinosity is less developed (or just worn out) have an appearance of darker brownish spots and stripes, especially in antero-median and mediolateral areas of praescutum. Pronotum and cervical sclerites dark-brown, with several long hairs. Prescutal pits clearly visible, with bigger dark triangular spots just caudad. Pleurae somewhat darker brownish-yellow; katepisternum and anterior part of anepimeron with long yellowish hairs. A weakly-defined brown stripe runs from cervical region across anepisternum, anepimeron, and katatergite to fuse with dark lateral stripe on abdomen. Traces of even more indistinct and narrower stripe can be seen just above the bases of coxa. Halteres obscure-yellow, knobs somewhat darker. Legs rather long, yellow, tips of tarsi darker, coxa and trochanters with several long hairs.

Wings (Fig. 1) rather wide, wing membrane hyaline, cell $s c$ and stigmal area yellowish, veins yellow, dense dark macrotrichiae on vein $C$, similar but more sparce hairs on veins $R, R s, R_{1}, R_{2+3}, R_{4+5}, M_{1+2}, M_{3}$, $C u A_{1}$, and distal portion of $C u A_{2}$. A fringe of long thin hairs on posterior margin of wing. Anal angle welldefined. Wing patterned with numerous small brown- ish-grey spots, sometimes confluent, several more distinct dark areas along anterior margin of wing, 1) over arculus; 2) midway between arculus and origin of $R s$; 3 ) at origin of $R_{s} ; 4$ ) at fork of $\left.S c ; 5\right)$ on $S c_{2}$ and $R_{2}$. Venation: supernumerary cross-vein in cell $s c$ present, $S c$ forked at approx. 0.4 length of $R s$, cell $d m$ present, cross-vein $\mathrm{m}-\mathrm{cu}$ approx. 0.4 its length before fork of $M$, apex of $A_{2}$ well before the origin of $R s$, slightly curved.

Abdomen cylindrical, with dark-brown pleural membranes, covered with long yellowish hairs, tergites brownish-yellow, sternites yellow. The anterior part of the 6th abdominal segment laterally with very conspicuous tufts of 15 long brownish-yellow hairs (Fig. 4), their length up to 0.7 length of the segment, these hairs up to 5 times longer than those forming regular pilosity of abdominal segments. Hypopygium (Figs 5-6) of moderate size, yellow. Tergite 9 transverse, almost 3 times wider than long, with a thin dark median keel not reaching its anterior margin; anterior margin sinuate, posterior margin very gently concave, extreme lateral areas strongly sclerotised, darkened. Gonocoxites elongate-cylindrical, slightly curved, twice as long as wide, each with a short dorsomesal lobe and a long ventromesal lobe; ventromesal lobe approx. 3 times longer than dorsomesal lobe. Apices of dorsomesal lobes with dense tufts of 7 long erect hairs, those of ventromesal lobes with a series of hairs of unequal length (the longest 2 times shorter than hairs on dorsomesal lobes). Ventral gonostyli elongate-elliptical, slightly longer than gonocoxites, with rostral projections moderately curved, rounded at apex, bearing 2 short erect spines at midlength, several short hairs at apex and additionally with a pencil of 3 long erect hairs at base (Figs 7-8). Length of rostral projections is roughly equal to maximum width of ventral gonostyli. Dorsal gonostyli equal in length to gonocoxites, moderately sclerotised, cylindrical, gently curved, more strongly and abruptly curved near bases and at apices, apices darkened, with acute and somewhat produced tips. Aedeagal complex (Figs 9-11) rather stout; penis triangular, curved, with 2 tubercles at apex; parameres triangular, strongly sclerotised, with simple pointed apices, slightly curved mesad. Proctiger is a transparent membraneous structure in the form of a folded ribbon, its obtuse apical part with two pigmented tuberculate lobes.

Female unknown.

ETYMOLOGY. The adjective 'scopifera' (sg.fem.nom.) is derived from the Latin noun 'scopa', meaning 'brush', and the verb 'fero', 'to bear'.

DISCUSSION. By the structure of male genitalia the new species is similar to Rhipidia (s. str.) choprai Alexander, 1927 [Alexander, 1927, pp.184-186] yet differs from it in some details and wing pattern as well (in Rhipidia choprai, eyes of male non-holoptic, 3 rostral spines, wings of male nearly unspotted, pectination of antennae different, tufts of hairs on abdominal segment 6 , a character too distinctive to be overlooked by previous authors, are absent).

DISTRIBUTION. India. 

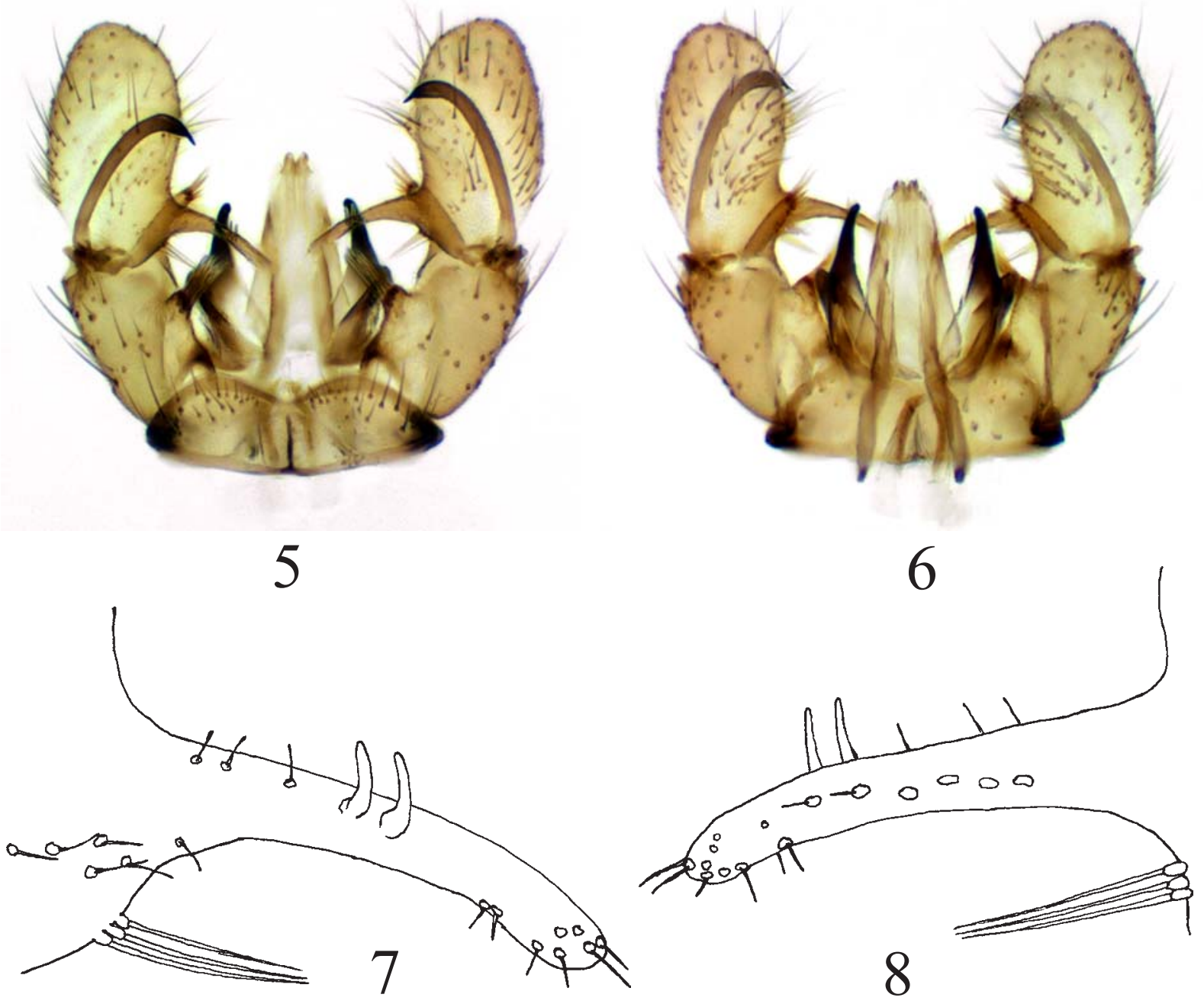

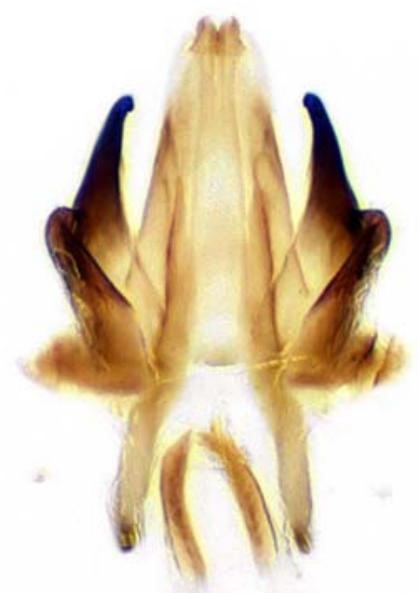

9

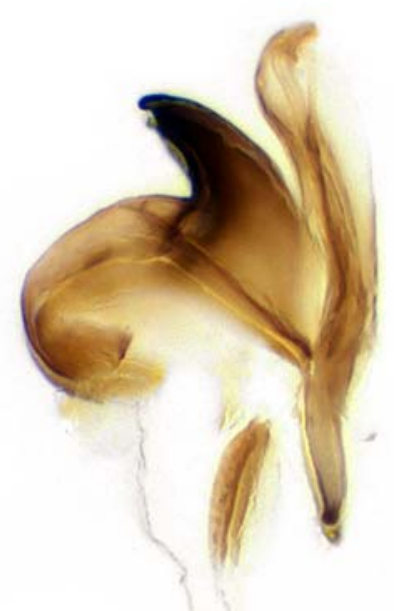

10

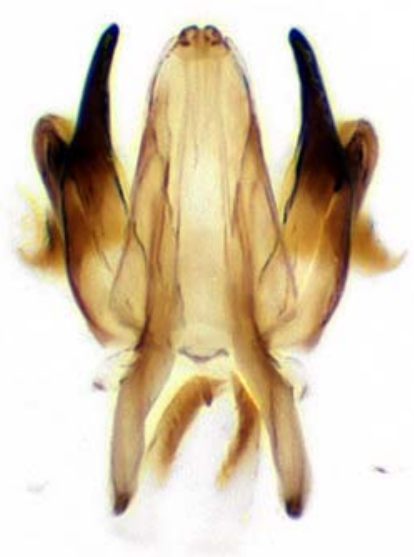

11

Figs 5-11. Rhipidia scopifera sp.n., paratype $0^{7}: 5-$ hypopygium, dorsal view; 6 - same, ventral view; 7 - left rostral projection, dorsal view; 8- same, ventral view; 9 - aedeagal complex, dorsal view; 10 - same, lateral view; 11 - same, ventral view.

Рис. 5-11. Rhipidia scopifera sp.n., паратип О7: 5 - гипопигий, вид сверху; 6 - то же, вид снизу; 7 - левый ростральный выступ, вид сверху; 8 - то же, вид снизу; 9 - эдеагус, вид сверху; 10 - то же, вид сбоку; 11 - то же, вид снизу. 

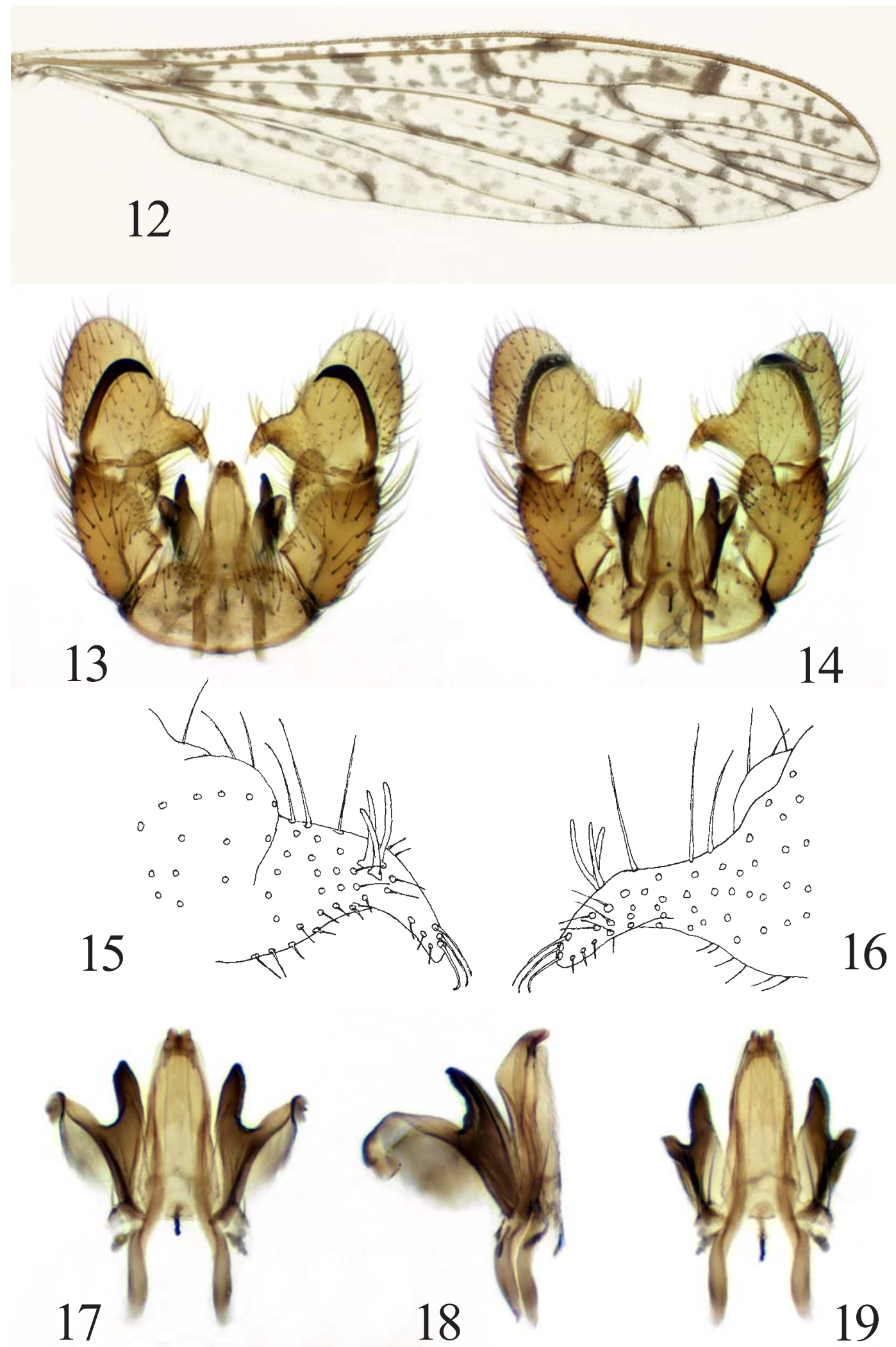

Figs 12-19. Rhipidia schwarzi Alexander, $0^{7}: 12$ - wing; 13 - hypopygium, dorsal view; 14 - same, ventral view; 15 - left rostral projection, dorsal view; 16 - same, ventral view; 17 - aedeagal complex, dorsal view; 18 - same, lateral view; 19 - same, ventral view. Рис. 12-19. Rhipidia schwarzi Alexander, $0^{7}: 12$ - крыло; 13 - гипопигий, вид сверху; 14 - то же, вид снизу; 15 - левый ростральный выступ, вид сверху; 16 - то же, вид снизу; 17 - эдеагус, вид сверху; 18 - то же, вид сбоку; 19 - то же, вид снизу. 
Rhipidia schwarzi Alexander, 1912

Figs 12-19.

Rhipidia schwarzi Alexander, 1912: 13.

MATERIAL EXAMINED. $1 \sigma^{\top}, 1$, Canary [Islands], Tenerife, N part, 25-31.III.2011, N. Vikhrev, attracted to light near a banana plantation (ZMUM).

Male, wing length $8.5 \mathrm{~mm}$ (Fig. 12); female, wing length $9 \mathrm{~mm}$. Male hypopygium is fully described and details of its structure are illustrated below.

DESCRIPTION. Male. Hypopygium (Figs 13-14) of moderate size, yellow. Tergite 9 transverse, approx. 2 times wider than long, its anterior margin sinuate, posterior margin concave, extreme lateral areas strongly sclerotised, darkened. Gonocoxites elongate-cylindrical, slightly curved, narrowed apically, twice as long as wide, each with a long ventromesal lobe; ventromesal lobe elongate-ellyptical, slightly narrowed at apex, approx. twice as long as wide, covered with sparse long and erect hairs. Ventral gonostyli elongate-elliptical, distinctly wider at base, roughly equal in length with gonocoxites, with weakly-defined wide dorsomesal lobe; rostral projections short, their length is roughly equal to minimum width of gonocoxites, strongly curved inwards, rounded at apex, bearing 3 strong and moderately curved spines approx. at two-thirds of their length, and 3 curved hairs at apex (Figs 15-16). Rostral spines approx. 1.5 longer than width of rostral projection at apex, brownish-yellow contrasting with other hairs on hypopygium which are dark. Dorsal gonostyli slightly shorter than gonocoxites, strongly sclerotised, especially at apices, cylindrical, gently curved, more strongly and abruptly curved at apices, apices darkened, with acute tips. Aedeagal complex (Figs 17-19) stout, with two setae at base on each side; penis triangular, widened at midlength, curved, with 2 tubercles at apex; parameres triangular, strongly sclerotised, rather slender, with simple pointed apices. Proctiger is a rather indistinct transparent membraneous structure.

REMARKS. Rhipidia schwarzi was described from St. Domingo and Cuba [Alexander, 1912]. This species belongs to domestica group and seems to be widely distributed in the New World, recorded from the United States of America (Florida), Dominican Republic, Puerto Rico, Jamaica, and Venezuela [Alexander, 1928; Alexander, 1964; Gelhaus et al., 1993; Oosterbroek, 2012]. Among a number of regional species with subpectinate antennae, their segments 12 and 13 contrastingly white or yellowish-white, similar wing pattern and praescutum broadly margined with yellowish-white in front and on sides, the only possible candidate seems to be Rhipidia luxuriosa (Alexander, 1929) described from Colombia. But the lateral light-yellow praescutal margins very conspicuous in $R h$. schwarzi are not mentioned for $R h$. luxuriosa, wing pattern is brighter and better-defined [cf. Alexander, 1916, plate II, fig. 2, as Rh. vicina]; moreover, the holotype of $R h$. luxuriosa is a female so it's impossible to compare males of these two similar species with enough confidence.

ACKNOWLEDGEMENTS. I wish to express my sincere gratitude to Dr. Andrey L. Ozerov (Zoological Museum of Moscow University, Moscow, Russia) for important corrections of the manuscript and kind assistance with difficult taxonomic issues, and Dr. Nikita E. Vikhrev (Zoological Museum of Moscow University, Moscow, Russia) for continuing encouragement and support.

\section{References}

Alexander C.P. 1912. On the tropical American Rhipidiae (Tipulidae, Dipt.) // Bulletin of the Brooklyn Entomological Society. Vol.8. P.6-17.

Alexander C.P. 1916. New or little-known crane-flies from Colombia, Ecuador and Peru (Tipulidae, Diptera) // Transactions of the American Entomological Society. Vol.42. P.1-32.

Alexander C.P. 1928. The crane-flies of Jamaica // Entomological Bulletin, Department of Agriculture. Vol.4. No.3. P.19-29.

Alexander C.P. 1927. The Oriental Tipulidae in the collection of the Indian museum. Part I // Records of the Indian Museum. Vol.29. P.167-214.

Alexander C.P. 1964. The crane-flies of Jamaica (Diptera, Tipulidae) // Bulletin of the Institute of Jamaica, Science Series. Vol.14. P.1-86.

Alexander C.P., Byers G.W. 1981. Tipulidae // J.F. McAlpine et al. (eds.). Manual of Nearctic Diptera 1. Research Branch, Agriculture Canada, Ottawa. Monograph No. 27. P.153-190.

Gelhaus J.K., Masteller E.C., Buzby K.M. 1993. Emergence composition and phenology of Tipulidae (Diptera) from a tropical rainforest stream at El Verde, Puerto Rico // Journal of the Kansas Entomological Society. Vol.66. No.2. P.160-166.

McAlpine J.F. 1981. Morphology and terminology - adults // J.F. McAlpine et al. (eds.). Manual of Nearctic Diptera 1. Research Branch, Agriculture Canada, Ottawa. Monograph No. 27. P.963.

Oosterbroek P. 2012. Catalogue of the Craneflies of the World ((Diptera, Tipuloidea: Pediciidae, Limoniidae, Cylindrotomidae, Tipulidae), online at: http://nlbif.eti.uva.nl/ccw/ (last accessed March 10, 2012). 